\title{
IMPLEMENTASI PETUNJUK TEKNIS IZIN OPERASIONAL PONDOK PESANTREN DALAM MENINGKATKAN PELAYANAN ADMINISTRATIF DI KEMENTERIAN AGAMA KABUPATEN LAMONGAN
}

\author{
Dewi Nur Kumala Sari, Muhammad Azam Kholilurrohman \\ UIN Sunan Ampel, Surabaya - Indonesia I dewinurks247@gmail.com
}

\begin{abstract}
Abstrak: Tujuan dari penelitian ini adalah untuk mendeskripsikan pelayanan administratif di Kementerian Agama Kabupaten Lamongan dalam melayani pengajuan izin operasional pondok pesantren. Penelitian ini menggunakan metode deskriptif analitik dengan pendekatan Kualitatif. Subjek penelitiannya adalah Kepala Seksi Pendidikan Diniyah dan Pondok Pesantren, Pengelola Data Pondok Pesantren, Pengembangan Kurikulum Evaluasi Pondok Pesantren, Pengelola Bantuan Operasional Pondok Pesantren, Pengelola Pendidikan Pondok Pesantren.Setelah dilakukan penelitian ini, dapat disimpulkan bahwa Kementerian Agama Kabupaten Lamongan telah melayani permohonan izin operasional pondok pesantren sesuai Keputusan Direktur Jenderal Pendidikan Islam Nomor 3668 Tahun 2019 dengan mengikuti perkembangan era digital saat ini yakni melalui situs web Direktorat Pendidikan Diniyah dan Pondok Pesantren.
\end{abstract}

Keywords: pesantren, administratif, pelayanan

\section{Pemdahuluan}

Istilah pesantren di Indonesia lebih populer dengan sebutan Pondok Pesantren, lain halnya dengan pesantren, pondok berasal dari kata bahasa Arab yang berarti hotel, asrama, rumah, dan tempat tinggal sederhana (Hasbullah, 1996: 138). Adapun pengertian pesantren, berawal pengertian: Pesantren berasal dari kalimat santri dengan tambahan awal pe dan akhiran an berarti tempat tinggal para santri (Dhofier, 1990: 18).

Pesantren adalah suatu lembaga pendidikan Islam dimana para santrinya tinggal di pondok yang dipimpin oleh kiai. Para santri 
tersebut mempelajari, memahami dan mendalami, menghayati dan mengamalkan ajaran agama Islam dengan menekankan pada pentingnya moral keagamaan sebagai pedoman perilakunya dalam kehidupan sehari-hari.1

Sejak berdirinya pada abad yang sama dengan masuknya Islam hingg sekarang, pesantren telah bergumul dengan masyarakat luas. Pesantren telah berpengalaman menghadapi berbagai corak masyarakat dalam rentang waktu itu. Pesantren tumbuh atas dukungan mereka, bahwa menurut Husni Rahim pesantren berdiri didorong permintaan (demand) dan kebutuhan (need) masyarakat, 2 sehingga pesantren memiliki fungsi yang jelas. Fungsi pesantren pada awal berdirinya sampai dengan kurun sekarang telah mengalami perkembangan. Visi, posisi, dan persepsinya terhadap dunia luar telah berubah.

Laporan Mustofa Syarif dkk, menyebutkan pesantren pada masa yang paling awal (masa Syekh Maulana Malik Ibrahim) berfungsi sebagai pusat pendidikan dan penyiaran agama Islam.3 Kedua fungsi ini bergerak saling menunjang. Pendidikan dapat dijadikan bekal dalam mengumandangkan dakwah, sedang dakwah bisa dimanfaatkan sebagai sarana dalam membangun system pendidikan. Jika ditelusuri akar seajarah berdirinya sebagai kelanjutan dari pengemabangan dakwah, sebenarnya fungsi edukatif pesantren adalah membonceng misi dakwah. Misi dakwah Islamiyah inilah yang mengakibatkan terbangunnya system pendidikan.4

Landasan Ideologis Pendidikan Pesantren

Sebagai lembaga pendidikan Islam yang mengandung makna keaslian Indonesia (indigenous), posisi pesantren sebagai lembaga

\footnotetext{
${ }^{1}$ Kompri, Manajemen dan Kepemimpinan Pondok Pesantren, (Jakarta:

Prenadamedia Group, 2018), 3.

${ }^{2}$ Husni Rahim, Arah Baru Pendidikan Islam di Indonesia, (Jakarta: Logos

Wacana Ilmu, 2001), 152.

${ }^{3}$ Mustofa Syarif, Suparlan S. dan Abd. Saleh, Administrasi Pesantren, (Jakarta: PT. Paryu Barkah, t.t.), 5.

${ }^{4}$ Marwan Saridjo, Sejarah Pondok Pesantren di Indonesia, (Jakarta:

Dharma Bhakti, 1982), 119.
} 
pendidikan Islam merupakan sub sistem pendidikan nasional. Karena itu, pendidikan pesantren memiliki dasar yang cukup kuat, baik secara ideal, konstitusional maupun teologis. Landasan ideologis ini menjadi penting bagi pesantren, terkait eksistensinya sebagai lembaga pendidikan yang sah, menyejarah dan penunjuk arah bagi semua aktivitasnya. Dasar ideal pendidikan pesantren adalah falsafah Negara Pancasila, yakni sila pertama yang berbunyi: "Ketuhanan Yang Maha Esa." Hal ini mengandung pengertian bahwa seluruh bangsa Indonesia percaya kepada Tuhan Yang Maha Esa, atau tegasnya harus beragama.5

Dasar konstitusional pendidikan pesantren adalah pasal 26 ayat 1 dan ayat 4 Undang-Undang Nomor 20Tahun 2003 Tentang Sistem Pendidikan Nasional. Padapasal 1 disebutkan bahwa, "Pendidikan non formal diselenggarakan bagi warga masyarakat yang memerlukan layanan pendidikan yang berfungsi sebagai pengganti, penambah, dan/atau pelengkap pendidikan formal dalam rangka mendukung pendidikan sepanjang hayat." Selanjutnya, pada pasal 2 dinyatakan, "Satuan pendidikan formal terdiri atas lembaga kursus, lembaga pelatihan, kelompok belajar, pusat kegiatan belajar masyarakat, dan majelis taklim, serta satuan pendidikan yang sejenis."6

Sedangkan dasar teologis pesantren adalah ajaran Islam, yakni bahwa melaksanakan pendidikan agama merupakan perintah dari Tuhan dan merupakan ibadah kepada-Nya. Dasar yang dipakai adalah Al-Qur'an dan Al-Hadist. Dasar Al-Qur'an sebagaimana disebutkan dalam Surat An-Nahl ayat 125:

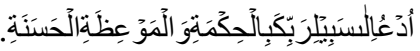

Artinya: "Serulah (manusia) kepada jalan Tuhanmu dengan hikmah dan pengajaran yang baik, dan berdebatlah dengan mereka dengan cara yang baik. ." (QS. An-Nahl: 125).

Di samping itu, pendidikan pesantren didirikan atas dasar

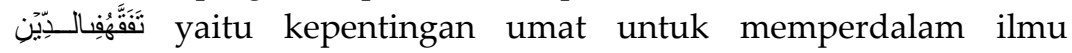

\footnotetext{
${ }^{5}$ Nurcholis Madjid, Bilik-Bilik Pesantren: Sebuah Potret Perjalanan, (Jakarta: Paramadina, 1997), 3.

${ }^{6}$ Undang-Undang Nomor 20 Tahun 2003 Tentang Sistem Pendidikan Nasional, (Jakarta: CV. Eko Jaya, 2003), 19-20.
} 
pengetahuan agama, dasar pemikiran ini relevan dengan firman Allah SWT:

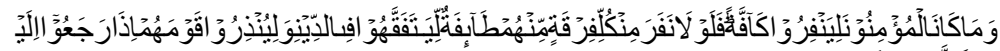

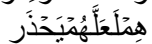

Artinya: "Dan tidak sepatutnya orang-orang mukmin itu semuanya pergi (ke medan perang). Mengapa sebagian dari setiap golongan di antara mereka tidak pergi untuk memperdalam pengetahuan agama mereka dan untuk memberi peringatan kepada kaumnya apabila mereka telah kembali, agar mereka dapat menjaga dirinya."(QS, At-Taubah:122).

Ayat tersebut di atas menjiwai dan mendasari pendidikan pesantren, sehingga seluruh aktivitas keilmuan di dalam pesantren pada dasarnya ditujukan untuk mempertahankan dan menyebarkan agama Islam.7 Selain ayat-ayat Al-Qur'an, dalam hadits Nabi juga banyak disebutkan landasan landasan teologis yang mendasari aktivitas pesantren, misalnya hadits riwayat Imam Bukhari: "Sampaikanlah ajaranku kepada orang lain walaupun hanya sedikit." (HR. Bukhari). Serta hadits riwayat Abu Daud dan Nasa'i: "Kamu pelajarilah kitab Allah dan kamu ikutilah apa yang ada di dalamnya." (HR.Abu Daud dan Nasa'i).

Ayat Al-Qur'an dan Hadits di atas merupakan perintah agama dan sekaligus mendasari kewajiban mencari ilmu pengetahuan dan mengajarkannya kepada orang lain walaupun sedikit. Keberadaan pesantren tidak lepas dari motivasi teologis tersebut. Bagi kalangan pesantren, menjalankan ajaran Islam dan mengeksplorasi ilmu pengetahuan adalah tugas sekaligus kewajiban yangharus diemban manusia untuk menjalankan fungsi kekhalifahannya di dunia dalam rangka mencari ridha-Nya. Dengan demikian, pesantren memerankan dirinya sebagai model pendidikan yang 'alim secara intelektual dan cerdas secara spiritual.

Dalam Undang-Undang Nomor 20 Tahun 2003 tentang Sisdiknas, Pasal 30 ayat (4) disebutkan bahwa, "Pendidikan keagamaan berbentuk pendidikan diniyah, pesantren, pasraman, pabhaja, samanera, dan bentuk lain yang sejenis". Selanjutnya

\footnotetext{
7Zamakhsyari Dhofier, Tradisi Pesantren: Studi Tentang Pandangan Hidup Kyai, (Jakarta: LP3ES Cet. VI, 1994), 17.
} 
dalam Peraturan Pemerintahan Nomor 55 Tahun 2007 tentang Pendidikan Agama dan Keagamaan, disebutkan dalam 14 ayat (1) bahwa pendidikan keagamaan Islam berbentuk pendidikan diniyah dan pesantren. Sebagai turunannya dibuatlah Peraturan Menteri Agama Republik Indonesia Nomor 13 Tahun2014 tentang Pendidikan Keagamaan Islam.

Pada Bab II Pasal 4 disebutkan bahwa pesantren wajib menjunjung tinggi dan mengembangkan nilai-nilai Islam rahmahlil'ālamīn dengan menjunjung tinggi nilai-nilai Pancasila, UUD 1945, Negara Kesatuan Republik Indonesia, Bhinneka Tunggal Ika, keadilan, toleransi, kemanusiaan, keikhlasan, kebersamaan, dan nilai-nilai luhur lainnya. Selanjutnya dalam Pasal 5 disebutkan bahwa pesantren wajib memiliki unsur-unsur yang terdiri atas kiai atau sebutan lainnya, santri, pondok atau asrama pesantren, masjid atau musholla, dan pengajian dankajian kitab kuning atau dirāsah islāmiyyah dengan pola pendidikan mu'allimin. Santri adalah peserta didik dan wajib bermukim di pondok atau asrama pesantren. Pesantren yang memiliki paling sedikit 15(lima belas) santri wajib mendaftarkan ke Kantor Kementerian Agama Kabupaten/Kota.

Untuk melindungi kekhasan pesantren, perlu adanya afirmasi negara untuk menjamin bahwa suatu lembaga layak dikatakan sebagai sebuah pesantren. Dalam hal ini, bentuk afirmasi tersebut diwujudkan dalam bentuk pemberian izin operasional pondok pesantren.

Izin operasional pondok pesantren merupakan bukti tertulis yang dikeluarkan oleh instansi yang berwenang melalui serangkaian proses dan prosedur yang telah dilalui terlebih dahulu sebagai legalitas atas kelayakan sebuah lembaga disebut pondok pesantren. Izin operasional ini lahir dari sejumlah tahapan yang telah dilalui terlebih dahulu untuk memastikan akan terpenuhinya persyaratan dan proses yang telah ditentukan. Persyaratan dan proses didasarkan atas landasan argumentasi-regulatif dan kebijakan teknis-operasional untuk memastikan kelangsungan orientasi dan khittah pondok pesantren, yang sejalan baik dari sisi kepentingan kebijakan maupun kepentingan kultural di 
masyarakat. Izin operasional merupakan bukti konkret dan sah bahwa sebuah instansi disebut pondok pesantren. Lembaga yang telah memiliki izin operasional ini berhak untuk menjalankan fungsi-fungsi yang melekat pada pondok pesantren, seperti fungsi pendidikan, fungsi transformasi ajaran agama, dan fungsi sosial lainnya dan diakui oleh negara.

Izin operasional bersifat temporer, dibatasi waktunya, yakni 5 (lima) tahun. Pembatasan waktu izin operasional ini dimaksudkan untuk memudahkan dalam melakukan pemutakhiran (updating) data, di samping untuk memudahkan upaya pembinaan dan peningkatan pondok pesantren. Dengan diterbitkannya izin operasional, pondok pesantren yang bersangkutan secara hukum telah diakui (recognize) oleh instansi yang berwenang untuk melakukan kegiatan dan program sesuai dengan tugas dan fungsi yang melekat pada pondok pesantren dan berhak untuk mendapatkan pembinaan, fasilitasi, dan hal-hal lain yang melekat berdasarkan peraturan perundang-undangan.

Data dan informasi terkait izin operasional pondok pesantren merupakan satu kesatuan data dan informasi pada Kementerian Agama, dengan pengelolaan sebagaimana ketentuan yang diatur melalui Keputusan Menteri Agama Nomor 440 Tahun 2018 tentang Pengelolaan Data dan Informasi Pada Kementerian Agama.

Posisi pesantren dalam fungsi pendidikan, fungsi dakwah, dan fungsi pemberdayaan masyarakat, tujuan pesantren, serta acuan umum mengenai unsur-unsur pesantren, ketentuan mengenai pendaftaran pesantren, ketentuan mengenai penyelenggaraan pesantren, dan ketentuan mengenai pengelolaan data dan informasi pada Kementerian Agama, menjadi dasar dalam menetapkan ketentuan lebih lanjut mengenai pendaftaran pesantren dalam bentuk izin operasional pondok pesantren. Ketentuan lebih lanjut tersebut, diperlukan dengan tujuan untuk menjamin efektivitas, efisiensi, transparansi, dan akuntabilitas proses yang terkait dengan izin operasional pondok pesantren. Oleh sebab itu, dipandang perlu untuk menyusun Petunjuk Teknis Izin Operasional Pondok Pesantren. 
Dengan latar belakang peneleitian yang fokus pada Petunjuk Teknis Izin Operasional Pondok Pesantren. Oleh karena itu, penelitian yang akan dilakukan berjudul Implementasi Petunjuk Teknis Izin Operasional Pondok Pesantren dalam Meningkatkan Pelayanan Administratif di Kementerian Agama Kabupaten Lamongan.

\section{Metodologi}

Penelitian ini menggunakan metode deskriptif analitik dengan pendekatan Kualitatif (P.D 2014)Lokasi penelitian di Kantor Kementerian Agama Lamongan, subjek penelitiannya adalah Kasi Pendidikan Diniyah Pondok Pesantren, Seksi-Seksi Pendidikan Diniyah Pondok Pesantren.

\section{Subjek Penelitian}

Sumber data primernya adalah seluruh jajaran yang ada di PD Pontren Kementerian Agama Lamongan yang meliputi Kepala Seksi PD Pontren, Pengelola Data Pontren, Pengembangan Kurikulum Evaluasi Pontren, Pengelola Bantuan Operasional Pontren, Pengelola Pendidikan Pontren. Sedangkansumber data sekundernya adalah berbagai dokumen dan data pendukung dataprimer yang ada di Kantor Kementerian Agama Lamongan berupa dokumen seperti buku-buku, artikel, jurnal ilmiah, surat, atau arsip.

\section{Prosedur}

Teknik pengumpula data dilakukan melalui; Pertama, wawancara. Wawancara dilakukan untuk mendapatkan data terkait implementasi Petunjuk Tekhnis Izin Operasional Pondok Pesantren dalam meningkatkan Pelayanan administratif di Kementrian Agama Kabupaten Lamongan. kepada Kepala Seksi PD Pontren, Pengelola Data Pontren, Pengembangan Kurikulum Evaluasi Pontren, Pengelola Bantuan Operasional Pontren, Pengelola Pendidikan Pontren. Kedua, observasi. Observasi dilakukan untuk memperoleh data dalam rangka memperkuat hasil wawancara. Observasi yang digunakan dalampenelitian ini yaitu observasi partisipatif yakni peneliti ikut melakukan kegiatanyang dilakukan narasumber. Ketiga, dokumentasi. 
Dokumentasi digunakan untuk melengkapi data sebelumnya yang didapat dari wawancara dan observasidi lapangan (Sugiyono,2014)8

\section{Analisis Data}

Analisis data dilakukan dengan memilih dan memilah data yang diperoleh, kemudian dikumpulkan untuk dianalisis dan diambil simpulan. Data yangtelah dikumpulkan dengan lengkap di lapangan, selanjutnya diolah dan dianalisis untuk menjawab masalah penelitian.

Tahap-tahap pengolahan data diantaranya: (Rijali,2019)9 Pertama pengumpulan. Dalam tahap ini penulis mengumpulkan datadari Kepala Seksi PD Pontren, Pengelola Data Pontren, Pengembangan Kurikulum Evaluasi Pontren, Pengelola Bantuan Operasional Pontren, Pengelola Pendidikan Pontren tentang. Implementasi Petunjuk Tekhnis Izin Operasional Pondok Pesantren dalam meningkatkan Pelayanan administratif di Kementrian Agama Kabupaten Lamongan. Data yang sudah terkumpul kemudian disusun dalam bentuk narasi-narasi, sehingga berbentuk rangkaian informasi yang bermakna sesuai dengan masalah penelitian.

Kedua,reduksi data. Pada tahap ini penulis melakukan pengelompokan terhadap informasi penting yang terkait dengan prosesimplementasi Petunjuk Tekhnis Izin Operasional Pondok Pesantren dalam meningkatkan Pelayanan administratif di Kementrian Agama Kabupaten Lamongansesuai topik masalah.

Ketiga, Analisis. Pada tahap ini penulis memberikan gambaran data hasil penelitian dengan prosedur sebagai berikut: data disajikan dalam bentuk deskripsi yang

\footnotetext{
${ }^{8}$ Sugiono,Metode Penelitian Pendidikan Pendekatan Kuantitatif, Kualitatif Dan R\&D MetodePenelitian Pendidikan Pendekatan Kuantitatif, 2014.
}

${ }^{9}$ Ahmad Rijsli,Analisis Data Kualitatif." Alhadharah: Jurnal Ilmu Dakwah, 2019. 
terintegrasi, data yang diperoleh dari hasil deskripsi akan dibandingkan dan dibahas berdasarkan landasan teori, kemudian penyajian hasil penelitian yaitu penulis tahap ini melakukan pengambilan kesimpulan untuk menjawab masalah yang telah dikemukakan peneliti.

Keempat, penyajian data. Data yang telah dianalisis diinterpretasikan berdasarkan hasil data yang didapatkan dari informan terhadap masalah yang diteliti yaitu implementasi Petunjuk Tekhnis Izin Operasional Pondok Pesantren dalam meningkatkan Pelayanan administratif di Kementrian Agama Kabupaten Lamongan.Data yang sudah direduksi dan diklarifikasikan berdasar kelompok masalah yang diteliti, sehingga memungkinkan adanya penarikan kesimpulan atau verifikasi terhadap pelaksanaan proses.

Kelima, penarikan kesimpulan. Padatahap ini penulis melakukan pengambilan kesimpulan berdasarkan susunan narasi yang telah disusun pada tahap ketiga, sehingga dapat memberi jawaban atas masalah penelitian.

\section{Hasil dan Pembahasan}

Keputusan Direktur Jenderal Pendidikan Islam Nomor 3668 Tahun 2019 Tentang Petunjuk Teknis Izin Operasional Pondok Pesantren dimaksudkan untuk memberikan ketentuan lebih lanjut mengenai pendaftaran pesantren dalam bentuk izin operasional pondok pesantren sehingga dapat menjadi acuan bagi semua pihak, serta bertujuan untuk menjamin efektivitas, efisiensi, transparansi, dan akuntabilitas proses yang terkait dengan izin operasional pondok pesantren.

Izin operasional pondok pesantren dapat diberikan kepada lembaga yang memenuhi persyaratan:

- Menyelenggarakan pesantren sekurangnya dalam fungsi pendidikan

- Mengembangkan nilai Islam rahmatul lil'alamin dan berlandaskan Pancasila, Undang-Undang Dasar 1945, NKRI, serta Bhinneka Tunggal Ika

- Memenuhi unsur pesantren (arkanul ma'had) 
- Berkomitmen dalam pencapaian tujuan umum pesantren yang sejalan dengan visi, misi, dan tujuan pembangunan nasional.

Secara fisik setidaknya ada 5 (lima) unsur harus terpenuhi secara integral oleh institusi pesantren (arknul ma'had) yaitu:

- Kyai atau sebutan lain sejenis

- Kyai memiliki kompetensi keagamaan dan kemampuan sosial

- Kyai memiliki kompetensi ilmu agama

- Berpendidikan pesantren atau pendidikan keagamaan Islam.

- Santri mukim

- Santri menetap di pesantren 24 (dua puluh empat) jam

- Santri kalong/tidak menetap, tetapi tidak menjadi bagian dari unsur pesantren.

- Pondok atau asrama pesantren

- Masjid atau mushola

- Kajian kitab kuning atau dirasah Islamiyah dengan pola pendidikan mual'limin

Membuat proposal pengajuan piagam pondok pesantren kepada kepala kantor kementerian agama. kemudian dilampiri dengan:

- Profil pondok pesantren (arus jumlah santri mukim pa / pi dan santri non mukim

- Surat pengantar dari kepala kua

- Pernyataan setuju dari RT / RW tentang keberadaan pondok pesantren dan diketahui oleh kepala desa / lurah dan camat.

- Susunan pengurus yayasan (jika ada yayasan)

- Susunan pengurus pondok pesantren

- Jadwal kegiatan belajar mengajar pondok pesantren dalam satu minggu

- Daftar pengajar / ustad pondok pesantren dilampiri fotocopy KTP

- Daftar nama dan alamat santri pondok pesantren teliti antara santri mukim (minimal 10 santri mukim) dan santri non mukim (sesuai blanko data emis) softcopy dan hardcopy. 
- Dilampiri foto bangunan pondok (plakat, kamar santri, ruang belajar, lapangan, dll) dan kegiatan santri (muhadloroh, olahraga, KBM, dll)

- Denah tanah dan bangunan pondok pesantren

- Peta lokasi pondok pesantren dari pusat kecamatan

- Fc. Akta notaris yayasan

- Fc. Akta tanah.

Kemeterian Agama pada saat ini telah berkembang sangat maju, itu dapat terbukti dengan jajaran media-media online yang digunakan untuk menampung segala macam kegiatan yang dinaungi oleh kementerian agama. Salah satunya yang khusus untuk Pendidikan Diniyah dan Pondok Pesantren yakni situs web Direktorat Pendidikan Diniyah dan Pondok Pesantren.

Situs web ini dihadirkan sebagai wujud Kementerian Agama dalam melayani umat khususnya layanan terhadap pendidikan diniyah dan pondok pesantren.Melalui website ini, ada 3 (tiga) layanan yang diberikan:

Pertama, situs web ini sebagai wujud pelayanan terhadap pendidikan diniyah dan pondok pesantren secara optimal. Tren saat ini, ada parameter perubahan yang optimalnya sebuah layanan, tidak hanya membangun kepuasan penerima manfaat layanan tetapi juga membangun loyalitas. Dari kepuasan pelanggan Ke loyalitas pelanggan .

Kedua, situs web diarahkan untuk memastikan program pembinaan dan pendampingan dalam rangka pengembangan kelembagaan pendidikan diniyah dan pondok pesantren dapat terlaksana dengan baik. Kita ingin memastikan bahwa setiap program dan kegiatan memiliki pengaruh dan manfaat bagi umat dan bangsa.

Ketiga, website ini juga untuk memastikan keberlangsungan pendidikan diniyah dan pondok pesantren yang kita kehendaki bersama. Kita berkewajiban untuk menjaga dan merawat pendidikan diniyah dan pondok pesantren dengan semua keunikan dan difungsi kelembagaannya.

Jadi, untuk pengajuan izin operasional pondok pesantren juga dilakukan secara online melalui website ini. Sistem layanan yang 
ada di kemenag hampir semua menggunanan online mulai dari perizinan maupun bantuan dana seluruhnya diatur didalam sebuah sistem aplikasi. Jadi, pengaruh petunjuk teknis yang ada dimana disitu memengaruh berbagai persyaratan yang harus dipenuhi setiap instansi.

Pemberian pelayanan yang baik merupakan salah satu upaya penyedia pelayanan untuk menciptakan kepuasan bagi para penerima pelayanan. Dengan kata lain jika layanan yang diberikan sesuai dengan harapan penerima layanan maka dapat dikatakan pemberi layanan tersebut mempunyai kualitas yang baik, tetapi sebaliknya jika layanan yang diberikan tidak sesuai dengan apa yang diharapkan maka dapat dikatakan kualitas layanan tersebut kurang baik.

Menurut Goetsch dan Davis dalam Ibrahim (2008:22) kualitas pelayanan merupakan suatu kondisi dinamis yang berhubungan dengan produk, jasa, manusia, proses dan lingkungan yang memenuhi atau bahkan melebihi harapan. Dengan kata lain Goetsch dan Davis beranggapan bahwa kualitas pelayanan juga diartikan sebagai sesuatu yang berhubungan dengan terpenuhinya harapan / kebutuhan pelanggan (masyarakat), dimana pelayanan dikatakan berkualitas apabila dapat menyediakan produk atau jasa sesuai dengan kebutuhan masyarakat.

Dalam menganilis kualitas pelayanan di kemenag, penulis menggunakan 5 dimensi menurut Zeithaml dkk 1990 dalam Hardiyansyah (2011:46-47) kualitas pelayanan dapat diukur dari 5 dimensi, yaitu : Tangible (berwujud), Reability (kehandalan), Responsiviness (ketanggapan), Assurancce (Jaminan), Emphaty (Empati). 10Pelayanan pada dasarnya adalah kegiatan yang ditawarkan oleh organisasi atau perorangan kepada konsumen yang dilayani yang bersifat tidak berwujud dan tidak dimiliki. Hal ini sesuai dengan apa yang disampaikan oleh Morman (dalam Suryanto, $2003: 8$ ),

\footnotetext{
${ }^{10}$ Ahmad Kevin Maulana, Endang Larasati, analisis Kualitas pelayanan administrasi kependudukan di kecamatan klari kabupaten karawang", jurnal pelayanan admistrasi kependudukian, Hal 7.
} 
Mengenai karakteristik tentang pelayanan yaitu: pelayanan bersifat tidak dapat diraba, pelayanan itu kenyataannya terdiri dari tindakan dan merupakan pengaruh yang sifatnya adalah tindakan sosial, produksi dan konsumsi dari pelayanan tidak dapat dipisahkan secara nyata, karena pada umumnya kejadiannya bersamaan dan terjadi di tempat yang sama.

Menurut Usman (2006 : 2) pengertian administrasi dalam pengertian sempit yaitu berhubungan dengan ketatausahaan. Sedangkan administrasi dalam pengertian sempit yaitu seni dan ilmu dalam mengelolah sumber daya $7 \mathrm{M}+1 \mathrm{i}$ (Man, money, material, methods, machines, marketing, and minutes + information) Brech (dalam Mills, 1991:4) memberikan batasan pengertian bahwa administrasi adalah bagian dari proses manajemen yang berhubungan dengan institusi dan pelaksanaan prosedur yang digunakan untuk menentukan dan mengkomunikasikan program dan perkembangan kegiatan diatur dan dicek berdasarkan target dan rencana.11

Dapat kita ketahui bahwasanya pengaruh layanan petunjuk teknis yang ada di kemenag lamongan sangat berpengaruh besar dalam menunjang sistem layanan administrasi, dimana kualitas pelayanan dapat diukur dari 5 dimensi, yaitu : Tangible (berwujud), Reability (kehandalan), Responsiviness (ketanggapan), Assurancce (Jaminan), Emphaty (Empati).

\section{Kesimpulan}

Petunjuk Teknis Izin Operasional Pondok Pesantren dimaksudkan untuk memberikan ketentuan lebih lanjut mengenai pendaftaran pesantren dalam bentuk izin operasional pondok pesantren sehingga dapat menjadi acuan bagi semua pihak, serta bertujuan untuk menjamin efektivitas, efisiensi, transparansi, dan akuntabilitas proses yang terkait dengan izin operasional pondok pesantren.

\footnotetext{
${ }^{11} Y u r i k o$ Abdussamad, "sistem pelayanan admnistrasi", jurnal pelayanan amnistrasi, $\mathrm{Hal} 7$.
} 
Suatu petunjuk tekhnis yang terukur menjadikan sebuah peningkatan dalam sistem yang ada dikantor semakin efisien. Pemberian pelayanan yang baik merupakan salah satu upaya penyedia pelayanan untuk menciptakan kepuasan bagi para penerima pelayanan.

Dengan kata lain jika layanan yang diberikan sesuai dengan harapan penerima layanan maka dapat dikatakan pemberi layanan tersebut mempunyai kualitas yang baik, tetapi sebaliknya jika layanan yang diberikan tidak sesuai dengan apa yang diharapkan maka dapat dikatakan kualitas layanan tersebut kurang baik.

Dari sebuah petunjuk teknis yang sesuai dengan persyaratan maka, layanan administrasi yang ada di Kemenag Kabupaten Lamongan asemakin maju dan canggi, sekarang semua layanan administrasi berbasis dengan sistem online menunjukkan sebuah draf kemajuan dari Kemenag Lamongan.

\section{References}

Dhofier, Zamakhsyari. 1994. Tradisi Pesantren: Studi Tentang Pandangan Hidup Kyai, (Jakarta: LP3ES Cet. VI,).

Kompri, 2018. Manajemen dan Kepemimpinan Pondok Pesantren, (Jakarta: Prenadamedia Group).

Madjid, Nurcholis. 1997. Bilik-Bilik Pesantren: Sebuah Potret Perjalanan, (Jakarta: Paramadina,).

Rahim, Husni. 2001. Arah Baru Pendidikan Islam di Indonesia, (Jakarta: Logos Wacana Ilmu,).

Rijsli, Ahmad. 2019. Analisis Data Kualitatif." Alhadharah: Jurnal Ilmu Dakwah,.

Sugiono, 2014. Metode Penelitian Pendidikan Pendekatan Kuantitatif, Kualitatif Dan R\&D MetodePenelitian Pendidikan Pendekatan Kuantitatif,.

Saridjo, Marwan. 1982. Sejarah Pondok Pesantren di Indonesia, (Jakarta: Dharma Bhakti,). 
Syarif, Mustofa, Suparlan S. dan Abd. Saleh, Administrasi Pesantren, (Jakarta: PT. Paryu Barkah, t.t.).

Undang-Undang Nomor 20 Tahun 2003 Tentang Sistem Pendidikan Nasional, (Jakarta: CV. Eko Jaya, 2003).

Maulana, Ahmad Kevin, Endang Larasati, analisis Kualitas pelayanan administrasi kependudukan di kecamatan klari kabupaten karawang", jurnal pelayanan admistrasi kependudukian.

Yuriko Abdussamad, "sistem pelayanan admnistrasi", jurnal pelayanan amnistrasi. 